\title{
Perceptions of justice and extra-role behaviours of survivors after organisational restructuring at a consolidated bank in Nigeria
}

\author{
Authors: \\ Queen Omoruyi ${ }^{1}$ \\ Crispen Chipunza ${ }^{2}$ \\ Michael O. Samuel ${ }^{3}$

\section{Affiliations:} \\ ${ }^{1}$ Public Further Education \\ and Training College, King \\ Williams Town, South Africa \\ ${ }^{2}$ Department of Human \\ Resource Management, \\ Central University of \\ Technology, Bloemfontein, \\ South Africa \\ ${ }^{3}$ Department of Industrial \\ Psychology, University of Fort \\ Hare, South Africa

\section{Correspondence to:} \\ Michael Samuel \\ Email: \\ msamuel@ufh.ac.za \\ Postal address: \\ Private Bag X1314, Alice \\ 5700 , South Africa \\ Dates: \\ Received: 07 Dec. 2010 \\ Accepted: 15 May 2011 \\ Published: 22 July 2011 \\ How to cite this article: \\ Omoruyi, Q., Chipunza, C., \& \\ Samuel, M.O. (2011). \\ Perceptions of justice \\ and extra-role behaviours \\ of survivors after \\ organisational restructuring \\ at a consolidated bank \\ in Nigeria. SA Journal \\ of Human Resource \\ Management/SA Tydskrif vir \\ Menslikehulpbronbestuur, \\ 9(1), Art. \#344, 14 pages. \\ doi:10.4102/sajhrm.v9i1.344
}

Orientation: Perception of justice amongst survivors of organisational downsizing is crucial for extra-role engagements. Researchers have recorded extra-role behaviours because they are important for organisational efficiency and success.

Research purpose: The main objective of this study was to evaluate the relationship between employees' perceptions of justice and their organisational citizenship behaviour (OCB) after organisations downsize.

Motivation for the study: Many organisations that are downsizing do not seriously consider the unintended consequences of downsizing on the behaviour of survivors. This study intends to draw the attention of organisations that are downsizing to this oversight.

Research design, approach and method: The researchers used a quantitative research design and survey method for the study. They distributed a self-administered questionnaire to 130 employees from a population of 180 survivors at the head office of a commercial bank that recently downsized in Lagos, Nigeria.

Main findings: The research results showed that there was no fairness in the downsizing exercise. This resulted in low morale amongst survivors and unwillingness to engage in extrarole behaviours.

Practical/managerial implications: It is important for organisations that are downsizing to use a participative approach in order to achieve organisational efficiency and improve productivity after restructuring.

Contribution/value-added: The results of the study will give the managers of organisations, which are planning to downsize, a useful insight into how to plan the exercise, how to implement the plans, and how to manage the employees they will retrench and those they will retain after concluding the downsizing exercise.

\section{Introduction}

The study of employees' perceptions of workplace justice and the extent to which these perceptions affect job-related attitudes (like commitment and organisational trust) and behaviours (like organisational citizenship behaviour and intention to leave) have become very interesting to organisational behaviour researchers. They have become particularly interested in the fairness of organisations when they restructure and in the citizenship behaviour of employees who survive organisational restructuring.

Many organisations are facing problems of global competition, economic instability and changing technologies today. These problems demand organisational change strategies that will allow organisations to remain competitive at lower cost.

A strategy that many organisations use to manage these problems is to downsize. Downsizing, according to Robbins (2005), is reducing an organisation's workforce and unused assets in order to reduce costs and to improve efficiency, productivity and competitiveness. Some features that one commonly associates with downsizing are the uncertainty, anxiety and frustration that will have long-term effects on the dismissed workers as well as on the survivors of restructuring (Samuel, Osinowo \& Chipunza, 2009). The survivors in restructured organisations are particularly concerned about the extent of fairness (or justice) managers show. This concern could shape employees' work behaviours and attitudes positively or negatively. 
Organisational justice and its relationship with extrarole behaviour are the basic and important objectives of successful organisations in the competitive world of business. Achieving organisational justice, Chegini (2009) argues, is a kind of fulfilment in all activities, behaviours and tendencies of organisations and individuals. Chegini further argues that organisational justice is a basis for strategic thinking and value management and is the basis of all organisational values and principles. Injustice, according to Chegini, threatens organisational permanence and growth, the goals of organisations. Therefore, the established relationship between organisational justice, employee citizenship behaviour and organisational success has made the subject a compelling study for organisational practitioners and academic researchers.

\section{Overview of downsizing at the commercial bank in Nigeria (2005-2006)}

The reform of the banking industry (commonly called the consolidation exercise) that the Central Bank of Nigeria (CBN) carried out between 2005 and 2006 has left an indelible mark on the landscape of the banking industry in Nigeria.

The exercise 'consolidated' about 89 operating banks in Nigeria into 25 at the end of 2006 (Oluba, 2008). The main reason for the consolidation exercise, Oluba explains, was the belief that banks in Nigeria were not vigorously and suitably 'performing the traditional and modern day responsibilities expected of them as banks'. The consolidation exercise aimed to increase the strength, reliability and diversity in the banking system (Oluba, 2008). This, according to Oluba, would guarantee the depositors' money and create the enabling financial environment for the banks to contribute more actively to the economic development of Nigeria.

In order to make itself more efficient and competitive, the commercial bank the researchers studied merged with another commercial bank and acquired a third bank to form a bigger banking entity in 2005 (Greef, Ajiboye \& Adekeye, 2007). With this merger, it became necessary for the bank to downsize its workforce.

According to Adegboye (2008), the bank used two criteria to downsize the bank. The first criterion was to give longserving employees the option to resign voluntarily. The bank terminated the appointments of others and dismissed others outright without using any clear criteria.

The bank's managers prohibited employees from joining labour unions. This breaches article 20(1) of the Universal Declaration of Human Rights, which states that 'everyone has the right to freedom of peaceful assembly and association'. Nevertheless, the prohibition made the summary dismissal of employees possible. This clearly violates the principles of good labour practice.

The downsizing exercise affected the employees of the newly acquired bank most. Some employees left the consolidated bank willingly because they believed that their future in the new bank was bleak. The bank downgraded those who remained to lower positions (Adegboye, 2008). The bank excluded these employees from the bank's annual performance appraisal exercise, thus effectively making their promotion impossible for that financial year (Adegboye, 2008).

Therefore, Adegboyega noted, the managers of the bank created a demoralised workforce, whether intentionally or not. The perceptions of justice, of all the survivors of the downsizing, became a critical determinant of their willingness to engage in extra-role behaviour. The procedures the bank used to downsize on the one hand, and considerations about distributive and relational justice for the survivors on the other, caused this.

Clay-Warner, Hegtvedt and Roman (2005) contend that, although downsizing affects its victims more than it does the employees that remain (in terms of their attitudes, perception, and future choices of employment) it also affects the survivors. Clay-Warner et al., (2005) argue that, although the survivors keep their work and wages, their sense of job security and hope of reimbursement decreases. In other cases, the fear of job loss will make the survivors less committed to their work. This causes lower productivity and more resistance to change (Noronha \& D'Cruz, 2006).

Previous research findings (like those of Barrett-Howard \& Tyler, cited in Clay-Warner et al., 2005, p. 89) show that employees are better motivated and express more feelings of satisfaction when they feel that their employers have treated them fairly. Coyle-Shapiro, Kessler and Purcell (2004) note that 'employees who believe they have been treated fairly respond to change initiatives within the work environment with behaviours that reflect effort beyond the call of duty.' These behaviours, according to Coyle-Shapiro et al., are organisational citizenship behaviours. The consolidated bank needed these behaviours, according to Imasuen (2008), because of the low morale of employees before and after the downsizing exercise.

In the light of these perspectives about the restructuring exercise at the consolidated bank, the research questions this study addresses are:

- What are the perceptions of survivors about the managers' use of procedural and distributive justice strategies during downsizing?

- What effect do the survivors' perceptions have on their organisational citizenship behaviours (OCBs)?

The objectives of the study are to:

- determine the perceptions of the survivors about the managers' use of procedural and distributive justice during downsizing

- measure the extent to which the survivors engage in OCB

- analyse the relationships between the survivors' perceptions of justice and the extent to which they engage in OCB. 
The findings of this study will provide a basis for comparative studies on the downsizing process with regard to the effective use of organisational justice to reduce some of the elements that hinder survivors' engagement in OCB. This will add significantly to the existing literature on organisational downsizing.

The sections that follow give a theoretical review of perceptions of justice and OCB in relation to organisational downsizing, present the research methodology, research findings and discussion and state the limitations of the study. The article makes recommendations to organisations that are downsizing and gives suggestions for further research into perceptions of organisational justice and OCB as they relate to organisational downsizing.

\section{Literature review}

\section{Organisational justice theory and perceptions}

Perceptions of justice have been considered explanatory variables in organisational research (Nadiri \& Tanova, 2010). Organisational justice is a kind of fulfilment in all activities, behaviours and tendencies. It is the basis of all organisational values and principles (Chegini, 2009). Injustice threatens organisational performance and growth, the goals of organisational life.

According to Koopmann (2006), one can trace the theory of organisational justice back to Adams' (1965) equity theory, the basis of social comparison. Similarly, organisational justice theory, as Thornhill, Lewis, Millmore and Saunders (2000, p. 262) express it, provides a useful explanation of people's reactions to the things they receive (outcomes) and the means through which they achieved these outcomes (procedures).

Adams' equity theory (1965) posits that employees assesses their job inputs against their job outputs and then compare the ratio of their inputs to outputs with other employees' ratios of inputs and outputs (Schultz, Bagraim, Potgieter, Viedge \& Werner, 2003, p. 64). In other words, employees measure the effort they contribute to a job against the outputs (or rewards) they get for the effort they contributed. They then compare them with the effort other employees expend and what they get as a reward.

We can locate the implications of this theory in the procedures organisations use when they reward, punish, promote and dismiss employees. Schultz et al. (2003) contend that the survivors of organisational downsizing will always consider the procedures an organisation used when retrenching their fellow colleagues. Survivors then react negatively if they regard the procedures as unfair. According to Steiner and Bertolino (2006, p. 63), the survivors' perceptions of inequity create tension and this tension will motivate the survivors to reduce input in proportion to the unfairness they perceive.

The researchers' findings in the current study are consistent with the literature. These findings show a significant drop in morale amongst survivors and their willingness to engage in extra-role activities because of the injustice they perceived in the procedures organisations used during downsizing and when distributing rewards afterwards.

Organisational behaviour researchers (like Kickul, Lester \& Finkl, 2002; Robbins, Odendaal \& Roodt, 2004; Steiner \& Bertolino, 2006) have identified three types of organisational justice: distributive, procedural and interactional.

Ismail (2007) defines distributive justice as the perceived fairness of the amount and allocation of rewards amongst individuals'. Clay-Warner et al. (2005) define the basis of distributive justice theory as the fairness of the outcome of a decision. This predicts how survivors will react to the outcome of allocating and distributing rewards to the victims of downsizing. Clay-Warner et al. (2005) contend that the basis of the survivors' perception of distributive justice is how the expected outcomes and agreed rules compare with the actual outcomes.

Distributive justice has many interesting elements that help us to understand why survivors of downsizing may not see the methods organisations use to distribute outcomes as fair. Thornhill, Lewis, Millmore and Saunders (2000) posit that survivors will see unfairness if the criteria the organisations used seem to promote organisational needs, like performance and efficiency, at the expense of workers. Robbins, Odendaal and Roodt (2004) note that distributive justice influences employees' satisfaction more than procedural justice does. The fairer the outcomes, the more satisfied employees will be. Therefore, this suggests that managers must ensure transparency in how they make decisions about downsizing in order to improve job satisfaction and OCB (Robbins, Odendaal \& Roodt, 2004, p. 79).

The researchers' analysis in the present study supports these authors. The variable selection procedure suggests that the survivors' perceptions of breaches of psychological contracts and the methods of rewarding victims were the most important predictors of OCB.

Robbins, Odendaal and Roodt (2004, p. 140) refer to procedural justice as 'the perceived fairness of the process used to determine the distribution of rewards'. According to Steiner and Bertolino (2006), employees will see a process as fair when they can participate in the deliberations that lead to the decisions that affect them. This increases mutual trust and commitment to their organisations.

In other words, involving employees in decision-making processes increases their feeling of self-worth because they believe that their employers are treating them in a dignified and respectful manner. Furthermore, they will be more willing to accept the outcomes that have emerged from the participative processes. In addition to accepting the outcomes, Dayaram (2005) notes that, when survivors perceive that their organisations make fair decisions that lead to the downsizing outcomes, they are likely to engage 
in extra-role behaviour to reciprocate the fair treatment from their managers.

Clay-Warner et al., (2005) observe that employees see procedures as fair when the means organisations use to reach decisions, when downsizing, eliminate bias and allow for consistency in treating employees. Eliminating bias reflects the opinions of the affected people, guarantees the accuracy of information and the methods the organisations use to rectify wrong decisions, and ensures compliance with moral and ethical standards. They increase the survivors' perceptions of procedural fairness, loyalty, productivity and commitment to the organisation.

Losing a friend, or friends, because of downsizing has a great effect on the attitudes and behaviours of the survivors. Shah $(2000$, p. 103) states that the outcomes of downsizing become more painful to the survivors if they see their former colleagues suffering. This statement is consistent with the views of Robbins, Odendaal and Roodt (2004, p. 262), who assert that 'the reactions of survivors are determined by the process used in selecting those that were affected and how they were treated'. The survivors' perception that organisations have treated their colleagues unfairly will, as Robbins, Odendaal and Roodt (2004) infer, result in negative survivors' attitudes and behaviours towards the organisation. Procedural justice is important to survivors because of its implications for their own futures.

In addition to distributive and procedural justice, interactional justice is one of the components of organisational justice. Interactional justice, according to Aquino, Griffeth, Allen and Hom (1997), is the assessment of the genuineness, objectivity and value an authority has given employees during times of change.

The focus in the literature on interactional justice is on the employees' feelings about the fairness of the ways their organisations treated them and others during downsizing exercises (Thornhill et al., 2000, p. 264). In a brief explanation of the meaning of interactional justice, Steiner and Bertolino (2006, p. 66) posit that it is the communication criterion of fairness'. According to Steiner and Bertolino (2006), people respond to the quality of interpersonal encounters they experience during the implementation of organisational procedures. Interactional justice, in the context of downsizing, is important because communication helps to explain why people feel unfairly treated even though they think the procedures and outcomes of decisions were fair. For example, survivors will judge an organisation's future interaction with them based on how fairly it has treated the employees it has dismissed.

In a similar explanation, Othman (2008) relates interactional justice to interpersonal interactions between employees and their managers. The main contention of Othman (2008) and Steiner (2006) is that employees must see the interpersonal interaction or communication that happens during downsizing as truthful, respectful and justified.
Therefore, one can conclude that interactional justice affects the organisational citizenship behaviour of survivors and that this depends on how they evaluate the genuineness, propriety and objectivity of the communication process managers used during downsizing processes.

\section{Organisational citizenship behaviour}

The less traditional types of job behaviour are better avenues to follow to discover the relationship between perceptions of fairness and employee behaviour (Moorman, 1991, p. 845). These nontraditional behaviours are on-the-job behaviours that traditional job descriptions do not usually capture. Therefore, they are more likely to fall under one's personal control (Moorman, 1991, p. 845).

One example of nontraditional job behaviour is organisational citizenship behaviour. Rafferty, Maben, West and Robinson (2005) define organisational citizenship behaviours as those special employees' work behaviours that benefit the organisation. They are optional, not directly or openly acknowledged in the formal reward system, and promote the effective running of the organisation.

OCBs are beneficial and desirable from an organisational perspective. However, managers have difficulty eliciting their occurrence or punishing their absence through contractual arrangements and formal rewards because they are voluntary (Nadiri \& Tanova, 2009). OCB includes employees spending time to assist coworkers to complete tasks, volunteering to do things that their jobs do not really require but that benefit the organisation, readiness to adjust to change and courtesy.

OCB is very important for the success of any organisation. Here, Robbins, Odendaal and Roodt (2004) submit that organisations, which have employees who do more than the organisations require, are efficient and will out-perform those organisations whose employees do not. This is consistent with Koopmann (2006), who noted that the presence of OCB will help organisations to become more successful because there will be low turnover rates and dedicated workers. It will lead to greater productivity.

In reporting on the general situation of the survivors of the downsizing in the Nigerian banking sector, Imasuen (2008) concludes that the merger created many problems that required immediate solutions. It remains to be seen what immediate solutions the bank could use to arrest the general sense of disillusionment amongst the banking staff. This 'general sense of disillusionment' (Imasuen, 2008) will prevent the banking sector in Nigeria from developing the stable working environment necessary to reap the benefits of OCB.

Organ (1990) identified and described the five dimensions of OCB:

- conscientiousness, which means that employees perform well beyond the minimum required levels

- altruism, which means helping others 
- civic virtue, which suggests that employees participate responsibly in the political life of the organisation

- sportsmanship, which states that people do not complain but have positive attitudes

- courtesy, which means treating others with respect.

Research shows that helpful behaviour (altruism) is an important dimension of OCB (Ishak, 2005; Jahangir, Akbar \& Haq, 2004; Podsakoff, Mackenzie, Paine \& Bachrach, 2000). The definition of helpful behaviour that most scholars, like Lievens and Anseel (2004); Podsakoff et al. (2000); Ishak, (2005); Jahangir et al. (2004), most commonly accept is that it is a voluntary behaviour of selfless concern for the welfare of others. It involves helping others voluntarily, like helping those who are absent or helping to prevent workrelated problems and helping others to prevent unforeseen problems. Sportsmanship behaviour is another important component of OCB that is crucial to organisational success.

According to Lievens and Anseel (2004), sportsmanship is being able to tolerate more than is usual. It is a person's ability or willingness to endure an annoying situation without complaining. One of the features associated with organisational downsizing include work overload, role ambiguity and burnout. After downsizing, survivors may feel uncertain of their roles. Managers may assign them new positions that are very different from what they previously did or what they were trained to do. This may affect their feelings of job insecurity, as they will be unsure of their performance in the new role.

The study of Fried, Ben-David, Tiegs, Avital and Yeverchyahu (1998) revealed the effect of role clarity on performance. Their results showed that job performance increased over time when roles are clearer. Employees require sportsmanship behaviour in these conditions. Ishak (2005) also emphasises this attribute. Ishak states that the ability of an individual to endure an unfavourable situation without grumbling is sportsmanship behaviour. Podsakoff et al. (2000) went on to assert that sportsmanship goes beyond not grumbling when coworkers cause uncomfortable situations. It includes remaining positive when things are not going according to plan.

Conscientiousness is another discretionary behaviour that goes beyond the minimal requirements of organisations (Tayyab, 2005). Operating beyond the minimum behaviour levels organisations require will go a long way to improving organisational effectiveness and increasing productivity. Employees, who arrive early at work and leave late, avoid unnecessary breaks or take short lunch periods, make constructive suggestions and complete tasks before they are due will certainly add to organisational effectiveness and help organisations to achieve their goals. This behaviour, Tayyab observes, is the conscientiousness dimension of OCB.

Jahangir et al. (2004) and Ishak (2005) refer to this behaviour as personal initiative and it includes the optimum use of time. Examples are being punctual and having high attendance rates. However, Podsakoff et al. (2000, p. 517) argue that one can regard individual initiative as OCB only if the people willingly decide to do more than organisations formally require of them. Employees are conscientious when they voluntarily suggest ideas and innovative designs that will enable them to be more effective in performing their duties, put more interest, time and determination into completing tasks effectively, willingly undertake extra work and encourage others to follow suit.

Werner (2007) describes courtesy as another discretionary act of thoughtfulness and considerate behaviour that prevents work-related problems for others. Notifying employers if employees will be arriving late for work, notifying colleagues before they do things that might affect their jobs or informing coworkers of delays in work progress, especially in interrelated work schedules where one employee's input depends on another's output, are all courtesy behaviours. They allow for effective work coordination and planning, which are essential to achieving predetermined organisational goals.

Lievens and Anseel (2004, p. 300) define civic virtue as extra participation and being more concerned about the success of organisations. Some of these behaviours include voluntarily serving on committees and attending functions that improve the image of organisations (DiPaola \& Tschannen-Moran, 2001, p. 432).

Podsakoff et al. (2000, p. 525) define civic virtue as the 'willingness to participate actively in organisational governance such as, attending meetings, engage in policy debate, and express one's opinion about what strategy the organisation ought to follow'. They extend civic behaviour to monitoring organisations' environments for threats and opportunities and keeping up with changes in the industry that might affect them. Employees who ensure their organisations' best interests by reporting hazards or suspicious activities and locking doors after work (even at great personal cost) are engaging in civic virtues (Podsakoff et al., 2000, p. 525).

Podsakoff et al. (2000) enlarge the traditional dimensions of OCB to include organisational loyalty. This means that employees are consistently faithful to their organisations. Accordingly, they define organisational loyalty as:

- being supportive and protective of their organisations at all times

- being committed to their organisations always

- defending and promoting their organisations at all times.

This presupposes that employees promote and protect their organisations by presenting their good image to the community.

Farh, Zhong and Organ (2004) summarise this behaviour as 'allegiance to an organisation and promotion of its interests'. Another dimension of OCB that Podsakoff et al. (2000, p. 517) identified is organisational compliance. These are attributes that enable employees to adhere to their organisations' rules 
and procedures always. This suggests that employees obey the rules and regulations of their organisations even when they are not being watched or monitored.

A study by Podsakoff et al. (2000) shows that organisational compliance is what Smith (1983) calls generalised compliance. Graham (1991) calls it organisational obedience.

Podsakoff et al. (2000) call self-development another dimension of OCB. According to them, it is the employees' choice to participate in activities to improve their skills, knowledge and abilities to benefit their organisations. It is common practice for employees to participate freely in advanced training programmes, to attend professional conferences and workshops, to remain current about research findings relevant to their professions and to acquire new skills in order to improve their contributions to the success of their organisations.

\section{Theoretical foundations of organisational citizenship behaviour}

The bases of OCB are some assumptions, like social exchange theory. According to Greenberg and Colquih (2005), Eisenberger, Armeli, Rexwinkel, Lynch and Rhoades (2001) and Aryee, Budhwar and Chen (2002), the first thing that will motivate people to help each other is reciprocity. This means people will feel compelled to help those who have helped them in the past (Eisenberger et al., 2001, p. 42). The simple reason for this is that, in order to maintain a healthy and continuous relationship, it is proper and appropriate to reciprocate help. The motivation for both in-role and extrarole job performance, according to Greenberg and Colquih (2005, p. 359) is reciprocity. That is, 'for in-role performance, the reward system provides motivation to reciprocate job performance'. For extra-role performance, they state that the motivation to reciprocate is not reward, but the perceived socio-emotional outcomes like trust, fair treatment, support and respect. This, amongst others, explains the reason that employees are willing to go the 'extra mile' for their organisations if they feel their organisations are treating, or have treated, them fairly.

Another argument Greenberg and Colquih (2005, p. 359) raise about social exchange theory is based on the research findings of Blau (1964). They assert that Blau did not agree that the fundamental driving force of all kinds of exchange is reciprocity. Blau states that social exchange, according to Aryee et al. (2002, p. 267), is 'the voluntary actions of individuals that are motivated by the returns they are expected to bring and typically do in fact bring from others'. This suggests that people may feel obliged to reciprocate a good gesture because of self-interest. The importance of Blau's finding is in the link it creates between OCB and reciprocation (Greenberg \& Colquih, 2005). Aryee et al. (2002) and Greenberg and Colquih (2005) contend that employees may engage in OCB to reciprocate benefits because they want them to continue. Thus, Greenberg and Colquih (2005) posit that, when employees see their exchange relationship as social, they will feel obliged to reciprocate the benefits they received or to reciprocate through OCB.
Aryee et al., 2002, p. 268, state that the 'social exchange in an employment relationship may be initiated by an organisation's fair treatment of its employees'. That is, if employees believe that they are receiving fair treatment from their employers they are obliged to pay back the fair treatment in order to reciprocate.

According to Eisenberger, et al. (2001, p. 42), employees are motivated to reciprocate beneficial treatment by engaging in behaviours (like OCB) that will be valuable to their organisations. Greenberg and Colquih (2005, p. 361) note that the relationship between organisational justice, social exchange and OCB is the perception that fair treatment is a benefit. Jahangir et al. (2004, p. 80) suggest that employees' perceptions of fairness is based on how equitable they perceive organisational decisions and the procedures organisations use to reach them.

Research suggests that the perception of fairness, in the distribution of outcomes and the processes organisations use to make these decisions during downsizing, is an important determinant of survivors' commitment. For example, Williams (2004) states that survivors' commitment to organisations after downsizing depends mainly on the perceived fairness of the downsizing process. Williams further states that, for organisations to survive after downsizing, they need employees with high affective commitment.

\section{Affective commitment and organisational citizenship behaviour}

Various researchers (like Jahangir et al., 2004; McShane \& von Glinow, 2008) regard affective commitment as important to employees' engagement in OCB. Rafferty, Maben, West and Robinson (2005) suggest that employees with high affective commitment are willing to do more than their duties require for the benefit of their organisations. Affective commitment to organisations happens with little or no influence from formal incentives. McShane and von Glinow (2008) assert that employees with high effective commitment want to do more for their organisations. As a result, they tend to be absent from work less frequently and display more motivation and organisational citizenship. Affective commitment amounts to self-sacrifice that, although organisations do not impose or demand it, contributes to their smooth operation (Brown, Mowen, Donavan \& Licata, 2002). Similarly, Jahangir et al. (2004) note that the survival and prosperity of organisations depend largely on the willingness of employees to act as good citizens by exhibiting behaviours that exceed their call of duty.

Further research on organisational behaviour has revealed determinants of OCB other than the social and economic exchange relationship. Cardona, Lawrence and Bentler (2004, p. 220) carried out one of these studies.

It revealed that other organisational experiences that influence OCB do not use social exchanges as a basis. For example, the work scope and job perceptions, which are also determinants of $\mathrm{OCB}$, use individual job attributes rather 
than social exchanges as their bases. According to Cardona et al. (2004), work exchange relationships, like social exchange relationships, are based on implicit agreements, unlike economic exchanges that are based on explicit agreements. This suggests that employers cannot specify all the expected behaviours they require employees to exhibit in a contract. Therefore, (Brown et al., 2002) state that 'mutual expectations defining a work exchange evolve as the relationship matures and social norms changes'. They also contend that, although social and work exchanges are based on implicit agreements, this does not make them the same. The difference between the two is that work exchanges are specific to work activities whilst social exchanges involve undefined social interactions (Cardona et al., 2004, p. 224).

\section{Organisational justice and organisational citizenship behaviour}

Organ (1988a, 1988b, 1990) suggests that one can describe the empirically supported relationship between job satisfaction and $\mathrm{OCB}$ as one that reflects a relationship between perceptions of fairness and OCB. Drawing from Organ's arguments, Moorman (1991), Greenberg and Colquih (2005) conclude that, if one measured job satisfaction and perceptions of fairness, then perceptions of fairness, and not job satisfaction, would relate to OCB. Moorman further argues that, if job satisfaction comprises a large fairness component, then why should fairness relate to OCB.

In providing an answer to this question, Organ (1988b, 1990) suggests two reasons why fairness could predict citizenship behaviour. Firstly, Adams (1965) proposes in equity theory that conditions of unfairness will create tension in people that they will attempt to resolve.

Organ (1988a) suggests that one should consider OCB as an input for one's equity ratio and that raising or lowering one's level of OCB could be a response to inequity. Organ (1988b) went on to point out that changing OCB could be the strategy of choice because OCB is discretionary and lies outside formal role requirements. Therefore, a change in $\mathrm{OCB}$, in response to inequity, would probably be safer than trying to change behaviour to bring it in line with formal role requirements. If it were not safer, at least it would fall directly under personal control (Moorman, 1991, p. 846).

A second reason why perceptions of fairness could relate to OCB originates from Blau's (1964) definition of the difference between economic and social exchanges (Moorman, 1991, p. 846). Organ (1988b) believes that perceptions of fairness may influence OCB by prompting employees to define their relationship with an organisation as one of social exchange. The exchanges become ambiguous because social exchanges exist outside strict contracts. This allows discretionary and prosocial acts from employees (Moorman, 1991).

According to Organ (1988b, p. 553), 'the inherent ambiguity of such a system frees the individual to contribute in discretionary fashion without thinking that this will be acquiescence to exploitation'. Therefore, if employees consider themselves to be in conditions of social exchange, they may be more likely to exhibit OCB (Moorman,
1991). Aryee et al. (2002, p. 267) suggest that employment relationships are exchange relationships that could be social or economic. Greenberg and Colquih (2005) state that social relationships are based on the exchange of benefits between two parties, like employers and employees. This, in other words, means that if employees see their organisations' fair treatment as benefits, they will be motivated to reciprocate. One way of reciprocating, according to Greenberg and Colquih (2005), is by doing more than their jobs require.

There is recorded empirical support for the influence of perceptions of fairness on OCB. The studies of Dittrich and Carroll, Scholl, Cooper and McKenna (as cited in Moorman, 1991) found that perceptions of job and pay equity correlated significantly with extra-role behaviour. In addition, Konovsky and Folger (1991) present preliminary evidence to support relationships between procedural justice and altruism. Furthermore, Farh, Podsakoff and Organ (1990) studied the relationship between fairness, job satisfaction and OCB specifically. Although they measured fairness indirectly from reports of leader contingent reward behaviour, leader supportiveness and participative leadership behaviour, they found that fairness was a two-factor model of OCB (Moorman, 1991).

\section{Research design}

The researchers chose quantitative research for this study because its findings are mainly the products of the statistical summary and analysis that Shaughnessy and Zechmeister (1997) described. One of the advantages of quantitative research design, according to Blanche, Durrheim and Painter (2006), is that 'the findings are generalisable and the data are objective'. The researchers chose a quantitative design for this study because of its primary strengths. See Blanche et al. (2006).

\section{Research strategy}

The researchers collected information using the survey research method. This involved administering structured questions, in a questionnaire, to a sample of respondents they selected from a population (Ghauri \& Gronhaug, 2005).

\section{Research method}

\section{Participants}

The researchers drew the sample for this research from the 180 employees at the head office of a commercial bank that recently downsized in Lagos, Nigeria. The sample for the study comprised 130 survivors of the downsizing exercise. The researchers selected the sample randomly using probability sampling. The participants represented all categories of employees in the bank.

\section{Measuring instrument}

The researchers measured organisational justice using the scale that Mansour-Cole and Scott (1998) developed. They measured OCB using the scale Robinson and Morrison (2000) developed. 
Sections B and C of the measuring instrument consist of three and five questions respectively. The questions in both sections measured the survivors' perceptions of the employers' breaches of psychological contracts. Section E of the measuring instrument consists of 10 questions that measured perceptions of procedural and interactive fairness. Sections $F$ and $G$ consist of seven questions each. The researchers used them to measure perceptions of distributive justice and the survivors' willingness to engage in OCB.

The researchers used a five-point Likert scale to measure all the questionnaire items. The researchers tested the reliability of the measuring instrument using Cronbach's alpha coefficient (see Table 1).

\section{Data collection}

The researchers sought and obtained permission from the head of human resources at the bank's head office in Lagos, Nigeria. The bank appointed a human resources officer as contact person.

The researchers, with the assistance of the contact person, delivered 130 questionnaires to the research participants. After several phone calls and personal visits to the participants, the researchers received 92 completed questionnaires. This is a $71 \%$ return rate, which is adequate for the study.

\section{Data analysis}

The researchers analysed the data using the Statistical Package for Social Sciences (SPSS version 15.0). They used Spearman's correlation coefficient to determine the relationship between the variables of procedural justice, distributive justice and OCB.

According to McDonald (2009), researchers use Spearman's correlation coefficient when measuring two variables and one 'hidden' nominal variable or ranked variables. McDonald (2009) further states that researchers use the nominal variable to group items into pairs in order to determine the relationship between the variables.

The researchers used descriptive statistics, like frequency distributions, to analyse the data. These distributions give the frequency of responses and the percentages for each of the questions in the questionnaire. They determined statistical significance for all the tests at the 0.05 level of significance.

\section{Results \\ Descriptive statistics}

The following tables give the descriptive statistics for each section of the measuring instrument.

The questions in this table assessed the extent to which employees knew about the downsizing. The scale ranges from 1 ('not at all') to 5 ('completely informed'). The median for all the questions was 2 . This shows that the bank gave little information to employees. This means that more than half of the survivors felt that they received very little or no information. The mean of 1.86 supports this. This suggests that employees did not receive enough information about the downsizing exercise.

These variables deal with the bank's decision-making methods. The researchers used them to measure procedural justice.

The researchers assessed the employees' answers using a five-point Likert scale. The scale ranged from 1 ('strongly agree') to 5 ('strongly disagree').

The median for all the responses was 4, with the exception of item C4, which had a median of 3. These medians show disagreement and neutrality respectively. The median of 4 implies that more than half of the respondents disagreed with the decision-making methods. The means are also close to the medians, indicating that the survivors generally disagreed with the downsizing approach the bank used. Employees' disagreement with the decision-making methods could be because of their lack of involvement in the process. Their responses, which suggested their involvement in the downsizing process, made this clear.

The researchers measured the survivors' perceptions of breaches of psychological contracts and trust in managers using the statements in Table 4 . They recorded the responses

TABLE 1: Cronbach's alpha coefficient for testing the reliability of the questionnaire.

\begin{tabular}{lll}
\hline Section & Heading & Cronbach's alpha coefficient \\
\hline B & Amount of downsizing information (interactive justice) & 0.92 \\
C & Survivors' perceptions of the managers' decision-making methods (interactive justice) & 0.86 \\
D & Survivors' perception of breaches of psychological contracts and trust in managers & 0.62 \\
E & Procedural fairness and interactive fairness & 0.86 \\
F & Methods of rewarding victims (distributive justice) & 0.86 \\
G & Survivors' organisational citizenship behaviour & 0.73 \\
\hline
\end{tabular}

TABLE 2: Descriptive statistics for survivors' perception of the amount of downsizing information (section B).

\begin{tabular}{|c|c|c|c|c|c|}
\hline Variable & $N$ & Mean & Median & Minimum & Maximum \\
\hline (B1) How much information did the bank give to all employees about the organisation's need to downsize? & 92 & 1.8587 & 2 & 1 & 3 \\
\hline (B2) How much information did the bank give to all employees about how it would conduct the downsizing? & 92 & 1.9021 & 2 & 1 & 3 \\
\hline $\begin{array}{l}\text { (B3) How much information did the bank give to all employees about how the bank decided who was to stay } \\
\text { and who was to go? }\end{array}$ & 87 & 1.839 & 2 & 1 & 3 \\
\hline
\end{tabular}

$N$, used as means of number. 
TABLE 3: Descriptive statistics for survivors' perceptions of the bank's decision-making methods (section C).

\begin{tabular}{|c|c|c|c|c|c|}
\hline Variable & $N$ & Mean & Median & Minimum & Maximum \\
\hline (C4) The bank made unbiased job decisions & 92 & 3.4 & 3 & 1 & 5 \\
\hline (C5) The bank made sure that it heard all employees concerns before making job changes and elimination decisions & 92 & 3.9 & 4 & 1 & 5 \\
\hline (C6) The bank clarified decisions and provided additional information when employees requested it & 92 & 3.8 & 4 & 2 & 5 \\
\hline (C7) The bank applied all job decisions consistently to all affected employees & 92 & 3.8 & 4 & 2 & 5 \\
\hline (C8) Employees were allowed to challenge or appeal job decisions managers made & 92 & 4.2 & 4 & 1 & 5 \\
\hline
\end{tabular}

$N$, used as means of number.

TABLE 4: Survivors' perceptions of breaches of psychological contracts and trust in managers (section D).

\begin{tabular}{|c|c|c|c|c|c|}
\hline Variable & $N$ & Mean & Median & Minimum & Maximum \\
\hline (D9) I believe there were no choices left for top managers other than to downsize. & 92 & 2.4 & 2 & 1 & 5 \\
\hline (D10) I trust that management team members expressed their true feelings about important issues. & 92 & 2.46 & 2 & 1 & 4 \\
\hline (D11) I feel betrayed by my organisation. & 92 & 2.65 & 2.5 & 1 & 5 \\
\hline
\end{tabular}

(D11) I feel betrayed by my organisation.

$N$, used as means of number.

using a five-point Likert-scale. The scale ranged from 1 ('mostly nondescriptive') to 5 ('very descriptive').

The mean scores fell between 2.4 and 2.7. The mean scores represent nondescriptive to somewhat descriptive responses. This indicates that survivors had very little trust in their managers. That is, their perception is that the managers had failed to honour psychological contracts. These perceptions, according to Robinson and Morrison (2000), reduce survivors' trust, job satisfaction, intentions to remain, sense of obligation and extra-role performance. The findings of Rinkwest (2003) also show that, once survivors' perceive that their job security is threatened, their job performance and productivity will suffer. The survivors' commitment to the organisation could also change because of broken promises.

The mean of between 1 and 2 shows that, on average, the survivors' thought that the treatment they got from managers was unfair. The study that Kickul et al. (2002) conducted shows that the survivors' interpretation of how fairly managers treated victims can moderate the behaviour of survivors' after perceived breaches of psychological contracts. This is because survivors assess the organisation using its processes and the assistance that managers gave to the victims.

Therefore, the issue of fairness, like perceptions of fair treatment, is an important factor that determines survivors' commitment. Lal, Srinivas and Varma (2003) suggest that perceptions of legitimacy, personal benefits, procedural and distributive justice are some of the ways to manage downsizing effectively. The current study showed that managers implemented none of the suggestions of Lal et al. (2003).

\section{Relationship between survivors' perceptions of justice and the extent to which they are engaging in organisational citizenship behaviour}

The researchers computed paired correlations of the derived variables to determine the strength and direction of the relationship between the survivors' perceptions of justice and the extent to which they were engaging in OCB. Table 6 gives Spearman's correlation coefficients in a correlation matrix.

\section{Paired correlations of derived variables}

All the paired correlations in Table 6 were statistically significant except for the one between the amount of information the bank provided and OCB (B and G).

Table 6 shows that:

- no significant linear relationship between $B$ and $G$, that is, between the amount of information and OCB $(r=-0.14$, $p=0.191)$

- OCB $(\mathrm{G})$ had a positive correlation with $(\mathrm{C})$ managers' decision-making methods $(r=0.4, p=0.0001)$ and $(\mathrm{F})$ the methods of rewarding victims $(r=0.62, p<0.0001)$

TABLE 5: Descriptive statistics for survivors' perceptions of procedural and interactional fairness when downsizing (section E).

\begin{tabular}{|c|c|c|c|c|c|}
\hline Variable & $N$ & Mean & Median & Minimum & Maximum \\
\hline $\begin{array}{l}\text { (E12) When the bank made decisions about job changes and eliminations, my manager and others in management } \\
\text { treated me with respect and dignity }\end{array}$ & 92 & 1.95 & 2 & 1 & 4 \\
\hline (E13) When the bank made decisions about my job, managers were sensitive to my personal needs & 92 & 1.84 & 2 & 1 & 3 \\
\hline (E14) When the bank made decisions about restructuring, managers dealt with me truthfully & 91 & 1.78 & 2 & 1 & 3 \\
\hline $\begin{array}{l}\text { (E15) When the bank made decisions about job changes and eliminations, managers showed concern for my rights as } \\
\text { an employee }\end{array}$ & 91 & 1.98 & 2 & 1 & 3 \\
\hline (E16) The bank discussed the implications of downsizing decisions with me & 92 & 1.58 & 2 & 1 & 3 \\
\hline $\begin{array}{l}\text { (E18) When making decisions about job changes and eliminations, managers offered explanations that made sense to } \\
\text { me }\end{array}$ & 92 & 1.68 & 2 & 1 & 3 \\
\hline (E19) Managers explained very clearly all the decisions they made about the restructuring & 92 & 1.62 & 2 & 1 & 3 \\
\hline (E20) My organisation shows a great deal of concern for me & 92 & 1.83 & 2 & 1 & 3 \\
\hline (E21) Overall, I have personally benefited from the restructuring & 92 & 1.57 & 1 & 1 & 4 \\
\hline
\end{tabular}

$N$, used as means of number. 
TABLE 6: Paired correlations of derived variables.

\section{Correlated sections}

(B) Amount of downsizing information and (C) Survivors' perceptions of managers' decision-making methods

(B) Amount of downsizing information and (D) Survivors' perceptions of breaches of psychological contracts

(B) Amount of downsizing information and (E) Survivors' perceptions of procedural and interactive fairness

(B) Amount of downsizing information and (F) Methods of rewarding victims

(B) Amount of downsizing information and (G) Organisational citizenship behaviour

(C) Survivors' perceptions of managers' decision-making methods and (D) Survivors' perceptions of breaches of psychological contracts

(C) Survivors' perceptions of managers' decision-making methods and (E) Survivors' perceptions of procedural and interactive fairness

(C) Survivors' perceptions of managers' decision-making methods and (F) Methods of rewarding victims

(C) Survivors' perceptions of managers' decision-making methods and (G) Organisational citizenship behaviour

(D) Survivors' perceptions of breaches of psychological contracts and (E) Survivors' perceptions of procedural and interactive fairness

(D) Survivors' perceptions of breaches of psychological contracts and (F) Methods of rewarding victims

(D) Survivors' perceptions of breaches of psychological contracts and (G) Organisational citizenship behaviour

(E) Survivors' perceptions of procedural and interactive fairness and (F) Methods of rewarding victims

(E) Survivors' perceptions of procedural and interactive fairness and (G) Organisational citizenship behaviour

(F) Methods of rewarding victims and (G) Organisational citizenship behaviour

\begin{tabular}{ll} 
Correlation coefficient $(\boldsymbol{r})$ & $\boldsymbol{p}$-value \\
-0.3444 & 0.001 \\
0.4268 & $<0.0001$ \\
0.4863 & $<0.0001$ \\
-0.503 & $<0.0001$ \\
-0.1399 & 0.191 \\
-0.566 & $<0.0001$ \\
-0.372 & 0.0003 \\
0.3772 & 0.0003 \\
0.3949 & 0.0001 \\
0.3074 & 0.0034 \\
-0.7268 & $<0.0001$ \\
-0.5966 & $<0.0001$ \\
-0.4556 & $<0.0001$ \\
-0.2475 & 0.0194 \\
0.6181 & $<0.0001$ \\
\hline
\end{tabular}

- $\quad$ OCB $(\mathrm{G})$ had a negative correlation with (E) procedural and interactive fairness $(r=-0.25, p=0.0194)$ and trust in managers $(r=-0.6, p<0.0001)$.

These results are broadly consistent with previous research on the effects of distributive justice on survivors' OCB. As expected, survivors' perceptions of managers' decisionmaking methods (interactive and procedural justice) and perceptions of the methods of rewarding victims (distributive justice) had negative correlations with OCB.

They are consistent with Kickul et al.'s (2002) findings. Kickul et al. (2002) state that survivors' anger and frustration increase in situations where, apart from breaches of psychological contracts, there are also perceptions of unfair procedures and treatment. This will result in survivors' negative attitudes and behaviour, which will hinder their willingness to engage in $\mathrm{OCB}$.

The reason for this, according to Noronha and D'Cruz (2006), is that survivors use the manner in which organisations handle the downsizing exercise as a reference point to determine the organisations' culture and values. This, in turn, affects their OCB. This also agrees with the maxim of reciprocity and social exchange: survivors' perceptions of unfairness will make them reciprocate with reduced input.

Similarly, lack of trust in managers (see D 10 in Table 4) and lack of procedural fairness also correlated negatively with OCB. Although this study shows no significant correlation between the amounts of information and survivors' $O C B$, information is still the foundation for building trust between managers and employees. This helps to explain the survivors' lack of trust in managers, because according to Tourish and Hargie (2004), communicating with employees builds up trust and credibility, which are beneficial to organisations.

In the same vein, Robbins, Odendaal and Roodt (2004) reveal that transparency about how organisations make decisions about downsizing will improve survivors' attitudes, job satisfaction and perceptions of fairness. These, in turn, influence other behaviours like OCB. In other words, lack of information will result in dissatisfaction.
The present study supports these findings. This study shows that the amount of downsizing information:

- correlated negatively with the survivors' perceptions of the managers' decision-making methods $(r=-0.34, p=$ $0.0010)$ and the methods of rewarding victims $(r=-0.50$, $p<0.0001)$

- correlated positively with trust in managers $(r=0.43, p<$ $0.0001)$ and procedural and interactive fairness $(r=0.49$, $p<0.0001)$.

This means that little information about downsizing is associated with disagreement with the managers' decision-making methods, disagreement with the methods of rewarding victims, less trust in managers and little management-employee interaction.

The need for employees' participation in the downsizing process is also important for the survivors' trust in managers and the perceived fairness of the procedures and outcomes. This study found that negative perceptions of the managers' decision-making methods were associated with low trust in managers, the perception of a lack of procedural and interactive fairness and disagreement with the methods of rewarding victims.

This supports the research findings of Steiner and Bertolion (2006). They show that employees will see processes and outcomes as fair only when they are involved in the deliberations leading to the decisions. According to Conner (2003), another factor that might affect the survivors' perceptions of fairness is their perception of whether they can influence the process.

The respondents in this study saw the decision-making methods as unfair because they were not involved in the process. This is consistent with the findings of Paterson and Cary (2002). They show that employees' commitment increases when the processes of change, like downsizing, allow employees to express their views, participate in the decision-making processes and to appeal against unfair decisions. Processes like these increase the self-esteem and job satisfaction of survivors and, consequently, affect their OCB. 
This study also found that comparing the distribution of rewards, based on the theory of equity, was also true. The results show that distributive justice is an important determinant of survivors' OCB.

Conner found that distributive justice is associated with traditional equity theory, which involves perceptions of the fairness of distributing outcomes (Conner, 2003). Based on this theory, survivors will be more willing to engage in $\mathrm{OCB}$ if they perceived that organisations rewarded victims fairly. This, according to Corner (2003), shows that 'survivors define fairness or equity based upon the use of the "equity rule" or the notion of input to outcome ratio comparisons'.

Looking at the correlations between OCB and all the other variables, the coefficients of determination $\left(r^{2}\right)$ are all less than 0.4 . This shows that the variables explain no more than $40 \%$ of the variability in OCB. This suggests that these variables, individually, do not explain a lot of the variability in organisational behaviour.

\section{Regressing organisational citizenship behaviour}

The researchers regressed organisational citizenship behaviour to the other derived variables in order to determine the pattern and magnitude of their effects. They used three variable selection procedures (forward, stepped and backward) to select the most important predictors and the best model to use. Table 7 presents a summary of the variable selection processes for each procedure.

The forward-selection procedure suggested a model with the rest of the derived variables as predictors. However, in this model BD, DD and ED were not statistically significant, as reflected in $p$-values greater than the 0.05 significance level. The variables CD and FD together explain 47.3\% (model $R$-square) of the variability in the OCB. FD explains most of it $(42.7 \%)$ whilst CD explains only $5 \%$ (partial $R$-square). This variable selection procedure suggests that, of all the potential predictors the researchers used in this analysis, FD is the most important predictor of OCB. This concurs with the statement of Robbins et al. (2005), that distributive justice influences employees' satisfaction more than procedural justice does and the fairer the outcomes the more satisfied the employee will be.

$\mathrm{BD}, \mathrm{CD}, \mathrm{ED}, \mathrm{FD}$ and $\mathrm{GD}$ are the derived variables that correspond to sections $\mathrm{B}, \mathrm{C}, \mathrm{D}, \mathrm{E}, \mathrm{F}$ and $\mathrm{G}$ of the questionnaire.

There has been a breach of a psychological contract breach when either the employer or the employee thinks that the psychological contract has not been fulfilled.

CD denotes survivors' perceptions of managers' decision methods and survivors' perceptions of breaches of psychological contracts.

$\mathrm{C}(\mathrm{p}), F$ and Pr denote the degree of the relationship between CD.

The stepped-selection procedure entered the variables in the same way as the forward-selection procedure did and produced the same results. The difference with forward selection is that stepped selection suggests excluding $C D$ as a potential predictor of OCB. Variable FD remains the most important predictor of OCB.

TABLE 7: Regression of organisational citizenship behaviour (summary of forward-selection procedure).

\begin{tabular}{|c|c|c|c|c|c|c|c|}
\hline \multirow[t]{2}{*}{ Step } & \multirow[t]{2}{*}{ Variable entered } & \multirow{2}{*}{$\begin{array}{l}\text { Number } \\
\text { Vars in }\end{array}$} & \multicolumn{2}{|c|}{$R$-Square } & \multirow[t]{2}{*}{$C(p)$} & \multirow[t]{2}{*}{$F$ Value } & \multirow[t]{2}{*}{$\operatorname{Pr}>F$} \\
\hline & & & Partial & Model & & & \\
\hline 1 & $\begin{array}{l}\text { (FD) Methods of rewarding victims and Survivors' perceptions of breaches of psychological } \\
\text { contracts }\end{array}$ & 1 & 0.427 & 0.427 & 13.869 & 64.75 & $<0.0001$ \\
\hline 2 & $\begin{array}{l}\text { (CD) Survivors' perception of managers' decision methods and Survivors' perceptions of breaches of } \\
\text { psychological contracts }\end{array}$ & 2 & 0.046 & 0.473 & 7.968 & 7.47 & 0.0076 \\
\hline 3 & $\begin{array}{l}\text { (BD) Amount of downsizing information and Survivors' perceptions of breaches of psychological } \\
\text { contracts }\end{array}$ & 3 & 0.018 & 0.49 & 6.934 & 2.93 & 0.0904 \\
\hline 4 & $\begin{array}{l}\text { (ED) Survivors, perceptions of procedural and interactive fairness and Survivors' perceptions of } \\
\text { breaches of psychological contracts }\end{array}$ & 4 & 0.016 & 0.506 & 6.178 & 2.72 & 0.103 \\
\hline 5 & $\begin{array}{l}\text { (DD) Survivors' perceptions of breaches of psychological contracts and Survivors' perceptions of } \\
\text { breaches of psychological contracts }\end{array}$ & 5 & 0.013 & 0.519 & 6 & 2.18 & 0.1438 \\
\hline
\end{tabular}

CD denotes survivors' perceptions of managers' decision methods and survivors' perceptions of breaches of psychological contracts; $C(p), F$ and Pr denote the degree of the relationship between $C D$.

$B D, C D, E D, F D$ and $G D$ are the derived variables that correspond to sections $B, C, D, E, F$ and $G$ of the questionnaire.

TABLE 8: Regression of organisational citizenship behaviour (summary of stepped-selection procedure).

\begin{tabular}{|c|c|c|c|c|c|c|c|c|}
\hline \multirow[t]{2}{*}{ Step } & \multirow[t]{2}{*}{ Variable entered } & \multirow{2}{*}{$\begin{array}{l}\text { Variable } \\
\text { removed }\end{array}$} & \multirow{2}{*}{$\begin{array}{l}\text { Number } \\
\text { Vars In }\end{array}$} & \multicolumn{2}{|c|}{$R$-Square } & \multirow[t]{2}{*}{$C(p)$} & \multirow[t]{2}{*}{$F$ Value } & \multirow[t]{2}{*}{$\operatorname{Pr}>F$} \\
\hline & & & & Partial & Model & & & \\
\hline 1 & $\begin{array}{l}\text { (FD) Methods of rewarding victims and Survivors' perceptions of breaches of psychological } \\
\text { contracts }\end{array}$ & - & 1 & 0.427 & 0.427 & 13.869 & 64.75 & $<0.0001$ \\
\hline 2 & $\begin{array}{l}\text { (CD) Survivors, perception of managers' decision methods and Survivors' perceptions of } \\
\text { breaches of psychological contracts }\end{array}$ & - & 2 & 0.046 & 0.473 & 7.968 & 7.47 & 0.0076 \\
\hline 3 & $\begin{array}{l}\text { (BD) Amount of downsizing information and Survivors' perceptions of breaches of } \\
\text { psychological contracts }\end{array}$ & - & 3 & 0.018 & 0.490 & 6.934 & 2.93 & 0.0904 \\
\hline 4 & $\begin{array}{l}\text { (ED) Survivors' perceptions of procedural and interactive fairness and Survivors' } \\
\text { perceptions of breaches of psychological contracts }\end{array}$ & - & 4 & 0.016 & 0.506 & 6.178 & 2.72 & 0.1030 \\
\hline 5 & $\begin{array}{l}\text { (DD) Survivors' perceptions of breaches of psychological contracts and Survivors' } \\
\text { perceptions of breaches of psychological contracts }\end{array}$ & - & 5 & 0.013 & 0.519 & 6 & 2.18 & 0.1438 \\
\hline 6 & & (CD) & 4 & 0.009 & 0.51 & 5.492 & 1.49 & 0.2253 \\
\hline
\end{tabular}

CD denotes survivors' perceptions of managers' decision methods and survivors' perceptions of breaches of psychological contracts; $C(p), F$ and Pr denote the degree of the relationship between $C D$. 
The backward selection procedure also suggested excluding the variable $C D$ as a predictor of OCB. Finding FD as the most important predictor of OCB confirms 'the personal outcomes model' of Clay-Warner et al., 2005. This states that employees' evaluation of personal outcomes, like job satisfaction, uses the fairness of distributing outcomes mainly (Clay-Warner et al., 2005). According to this model, distributive justice is the most important predictor of job satisfaction.

\section{Discussion}

The main objective of this study was to evaluate the relationship between perceptions of justice and employees' engagement in OCB after organisations downsize.

This evaluation will provide the managers of organisations, which are planning to downsize, with useful insights into planning, implementing their plans and managing the victims and survivors of downsizing.

The results of this study will also add significant value to the theoretical evaluation of perceptions of organisational justice and of employee extra-role engagements during and after downsizing.

This study shows that there were flaws in the process of downsizing, particularly in the procedures the bank used and how it distributed rewards. This caused low morale amongst survivors and affected their unwillingness to engage in citizenship behaviours. Most survivors saw the procedures the bank used whilst downsizing, and in distributing rewards afterwards, as unfair.

The results support the research findings of Levitt, Wilson and Gilligan (2008). They conclude that organisations often do not achieve their objectives of downsizing because survivors:

- no longer feel a sense of team or purpose

- put limited effort into their work

- operate at high stress levels

- feel little job satisfaction

- distrust the organisation

- feel no loyalty.

The study also revealed that the bank did not involve employees before and after the downsizing exercise. This created an atmosphere of job insecurity for survivors and made them negative about extra-role behaviours.

The researchers make the recommendations that follow.

\section{Recommendations}

In order to motivate employees to engage in OCB, especially after downsizing, managers need to develop both proactive and reactive strategies to manage the process of downsizing. It is important for managers to involve employees in the process of downsizing from the planning stage to the end of the exercise.
This participative approach will tell employees how much managers value them and will demonstrate how fair the exercise is. Positive perceptions of justice will motivate employees to reciprocate by engaging in extra-role behaviours.

Communication becomes important here. Communication should be two-way in order to get the commitment and support of the employees. Transparent communication increases the trust survivors have in managers. It increases their loyalty to the organisation and their willingness to engage in OCB.

Organisations that downsize should ensure that they are fair when distributing rewards amongst survivors.

Managers should prioritise the welfare, especially the psychological welfare, of survivors through trauma programmes like counselling, assistance programmes, training and development to increase their sense of belonging. For example, counselling will enable the survivors to deal with the psychological trauma of downsizing exercises. Proactive training of the survivors will prepare them for new tasks ahead. Survivors need to be reassured about their jobs in organisations because a sense of job insecurity decreases their willingness to engage in OCB.

\section{Limitations of the study}

The respondents in this study were unable to express their ideas freely because the questions in the questionnaire used a Likert scale. This, to some extent, limited the respondents who might want to express opinions other than those the investigators gave in the questionnaire.

The researchers conducted the research at the bank's head office. They did not survey other branches of the bank or other banks that downsized in Nigeria.

Therefore, one should be careful about generalising the findings of this study to the whole of the banking sector in Nigeria.

\section{Suggestion for further research}

This study shows that all the variables the researchers considered accounted for only $51 \%$ of the variability in OCB. This suggests that other factors account for the rest of the variability in OCB. The current study failed to capture these.

Therefore, the researchers recommend that future research should establish other variables that affect OCB because $49 \%$ of the variables the researchers measured here did not predict survivors' OCB.

This research should be replicated in all the banks that restructured because of the consolidation exercise. The results of this research can be used as generalisable empirical evidence from the Nigerian banking sector. 


\section{Acknowledgements}

\section{Authors' contributions}

Crispen Chipunza, the principal investigator, collaborated with the authors on this research. Omoruyi designed the empirical study. Samuel provided the theory and adapted the article for publication in the journal.

\section{References}

Adams, J.S. (1965). Inequity in social exchange. In L. Berkowitz (Ed.), Advances in experiential Psychology (Vol.2, pp. 267-299). SanDiego, CA: Academic Press.

Adegboye, B.R. (2008). Reflecting Voices from Within. Unpublished term paper. Auchi Polytechnic, Auchi, Nigeria.

Aquino, K., Griffeth, R.W., Allen, D.G., \& Hom, P.W. (1997). Integrating justice constructs into the turnover process: a test of referent cognitions model. Academy of Management Journal, 40(5), 1208-1227. doi:10.2307/256933

Aryee, S., Budhwar, P.S., \& Chen, Z.X. (2002). Trust as a mediator of the relationship between organizational justice and work outcomes: Test of a social exchange model. Journal of Organizational Behavior, 23, 267-285. doi:10.1002/job.138

Blanche, M.T., Durrheim, K., \& Painter, D. (2006). Research in Practice. $2^{\text {nd }}$ Edn. Cape Town: University of Cape Town.

Blau, P. (1964). Exchange and power in social life. New York: Wiley.

Brown, T., Mowen, J., Donavan, D., \& Licata, J. (2002). The customer orientation of service workers: Personality trait determinants and effects on self-and superviso performance ratings. Journal of Marketing Research, 39, 110-119. doi:10.1509/ jmkr.39.1.110.18928

Cardona, P., Lawrence, B.S., \& Bentler, P.M. (2004). The Influence of Social and Work Exchange Relationships on Organisational Citizenship Behaviour. Group and Organisation Management, 29(2), 219-247. doi:10.1177/1059601103257401

Chegini, M.G. (2009). The relationship between organisational justice and organisational citizenship behaviour. American Journal of Economics and Business Administration, 1(2), 173-176. doi:10.3844/ajebasp.2009.173.176

Clay-Warner, J., Hegtvedt, K.A., \& Roman, R. (2005). Procedural Justice, Distributive Justice: How Experiences with Downsizing Condition Their Impact on Organisational Commitment. Social Psychology Quarterly, 68(1), 89-102. doi:10.1177/019027250506800107

Conner, D.S. (2003). Socially appraising justice: A cross-cultural perspective. Social Justice Research, 16, 29-39. doi:10.1023/A:1022922010184

Coyle-Shapiro, J.A.M., Kesler, I., \& Purcell, J. (2004). Exploring organisationally directed citizenship behaviour: reciprocity or 'it's my job'? Journal of Management Studies, 41(1), 85-106. doi:10.1111/j.1467-6486.2004.00422.x

Dayaram, K. (2005). Navigating Complexity: The Dynamics of Organisational Culture during a Merger. Research and Practice in Human Resource Management, 139(1),

D' Cruz, P. (2005). Downsizing Older Employees: A Study of India's Public Sector Banks. Korean Journal of Industrial Relations, 15(2), 1-33.

DiPaola, M.F., \& Tschannen-Moran, M. (2001). Organisational Citizenship Behaviou in School and Its Relationship to School Climate. Journal of School Leadership, 11, 424-447.

Eisenberger, R., Armeli, S., Rexwinkel, B., Lynch, P.D., \& Rhoades, L. (2001). Reciprocation of Perceived Organisational Support. Journal of Applied Psychology, 86(1), 42-51. doi:10.1037/0021-9010.86.1.42, PMid:11302232

Farh, J., Podsakoff, P.M., \& Organ, D. (1990). Accounting for organisational citizenship behaviour: Leader fairness and task scope versus satisfaction. Journal of Management, 16, 705-722. doi:10.1177/014920639001600404

Farh, J., Zhong, C., \& Organ, D.W. (2004). Organisational Citizenship Behaviour in the People's Republic of China. Organisational Science, 15(2), 241-253. doi:10.1287/ orsc.1030.0051

Fried, Y., Ben-David, H.A., Tiegs, R.B., Avital, N., \& Yeverchyahu, U. (1998). The interactive effect of role conflict and role amboguity on job performance. Journal of Occupational and Organisational Psychology, 7(1), 19-28.

Ghauri, P., \& Gronhaug, K. (2005). Research Methods in Business Studies. Dorset: Prentice Hall.

Chegini, M.G. (2009). The relationship between organisational justice and organisational citizenship behaviour. American Journal of Economics and Business Administration, 1(2), 173-176. doi:10.3844/ajebasp.2009.173.176

Graham, J. (1991). An essay on organizational citizenship behaviour. Employee Responsibilities and Rights Journal, 4, 249-270. doi:10.1007/BF01385031

Greenberg, J., \& Colquih, J.A. (2005). Handbook of Organisational Justice. New Jersey: Lawrence Erlbaum Associates.

Greeff, P., Ajibove, A., \& Adekeye, J. (2007). Global Credit Rating Company. Fidelity Bank PIc. Retrieved November 11, 2008, from http://www.globalratings.net

Imasuen, T. (2008). Human Resource Melt Down in Nigerian Banks. Unpublished article, Imasuen HR Consulting Services, Benin City, Nigeria.
Ishak, N.A. (2005). Promoting Employees' Innovativeness and Organisational Citizenship Behaviour through Superior-Subordinate Relationship in the Citizenship Behaviour through Superior-Subordinate Relationship in the
Workplace. Research and Practice in Human Resource Management, 13(2), 16-30.

Ismail, A. (2007). Relationship between Pay Distribution Systems, Distributive Justice and Work Attitudes and Behaviours within Malaysian Institutions of Higher Learning. Unitary E-Journal, 3(1), 1-22.

Jahangir, N., Akbar, M.M., \& Haq, M. (2004). Organisational Citizenship Behaviour: Its Nature and Antecedents. BRAC University Journal, 1(2), 75-85.

Kickul, J., Lester, S.W., \& Finkl, J. (2002). Promise Breaking during Radical Organisational Changes: Do Justice Interventions Make a Difference? Journal of Organisational Behavior, 23(4), 69-488. doi:10.1002/job.151

Konovsky, M.A., \& Folger, R. (1991). The effects of procedural and distributive justice on organisational citizenship behaviour. Unpublished manuscript, A.B Freeman School of Business, Tulane University.

Koopmann Jr, R., \& Tafalla, R. (2006). The Relationship between Perceived Organisational Justice and Organisational Citizenship Behaviours: A Review of the Literature. Retrieved July 03, 2008, from http://www.uwstout.edu/rs/uwsjsr/ koopmann.pdf

Lal, J.B., Srinivas, E.S., \& Varma, A. (2003). Employee Perceptions of Organisation during Downsizing: A Field Study. Retrieved March 23, 2009, from http://www. jgxysx.net/DAOM/o34_jaydeepBihariLal.pdf

Levitt, K., Wilson, T., \& Gilligan, E. (2008). Corporate downsizing: an examination of the survivors. Journal of Global Issues, 2(2), 1-10.

Lievens, F., \& Anseel, F. (2004). Confirmatory Factor Analysis and Invariance of an Organisational Citizenship Behaviour Measure Across Samples in a DutchSpeaking Context. Journals of Occupational and Organisational Psychology, 71, Speaking Context. Journals of Occupational

Mansour-Cole, D.M., \& Scott, S.G. (1998). Hearing it through the grapevine: the influence of source, leader-member relations, and legitimacy on survivors' fairness influence of source, leader-member relations, and legitimacy on survivors' fairness
perceptions. Personnel Psychology, 51, 25-54. doi:10.1111/j.1744-6570.1998. perception
tb00715.x

McDonald, J.H. (2009). Handbook of Biological Statistics. Baltimore: Spark House Publishing.

Mcshane, S.L., \& Von Glinow, M.A. (2008). Organisational behaviour, 4th Edn. NY: McGraw Hill.

Moorman, R.H. (1991). Relationship between organisational justice and organisational citizenship behaviours: Do fairness perceptions influence employee citizenship? citizenship behaviours: Do fairness perceptions influence employee citizenship?
Journal of Applied Psychology, 76(6), 845-855. doi:10.1037/0021-9010.76.6.845

Nadiri, H., \& Tanova, C. (2010). An investigation of the role of justice in turnover intentions, job satisfaction, and organisational citizenship behaviour in hospitality industry. International Journal of Hospitality Management, 29(1), 33-41. doi:10.1016/j.ijhm.2009.05.001

Noronha, E., \& D'Cruz, P. (2006). A Necessary Evil: The Experiences of Manager Implementing Downsizing Programme. The Qualitative Report, 11(1), 88-112.

Oluba, M.N. (2008). Basic Thoughts on Reversing the Trend of Financial Exclusion in Nigeria. Retrieved n.d. from http//www.martinoluba.com, Vol. (B): 21

Organ, D.W. (1988a). Organisational citizenship behaviour: The good soldier syndrome. Lagos: Lexington Books.

Organ, D.W. (1988b). A restatement of the satisfaction-performance hypothesis Journal of Management, 14, 547-557. doi:10.1177/014920638801400405

Organ, D.W. (1990). The motivational basis of organisational citizenship behaviour. In B.M. Staw \& L.L. Cunnings (Eds.), Research in organisational behaviour (Vol. 12, pp. 43-72). Greenwich, CT: JAI Press.

Othman, R. (2008). Organisational Politics: The Role of Justice, Trust and Job Ambiguity. Retrieved April 03, 2008, from http:www.enotes.com/Singaporemanagement-revial-journals/174010301

Paterson, J.M., \& Cary, J. (2002). Organisational Justice, Change Anxiety, and Acceptance of Downsizing: Preliminary Tests of an AET-Based Model. Motivation and Emotion, 26(1), 83-103. doi:10.1023/A:1015146225215

Podsakoff, P.M., Mackenzie, S.B., Paine, J.B., \& Bachrach, D.G. (2000). Organisational Citizenship Behaviours: A Critical Review of the Theoretical and Empirical Literature and Suggestions for Future Research. Journal of Management, 26(3), 513-563. doi:10.1177/014920630002600307

Rafferty, A.M., Maben, J., West, E., \& Robinson, D. (2005). Organisational Citizenship Behaviour - What Makes a Good Employer? International Council of Nurses Journal, 3, 47-51.

Rinkwest, S.L. (2003). The interrelationships among job insecurity, locus of control, sense of coherence and organisational commitment of survivors of downsizing. Unpublished masters degree dissertation, University of the Western Cape, Bellville, South Africa.

Robinson, S.L., \& Morrison, E.W. (2000). The Development of Psychological Breach and Violation: A Longitudinal Study. Journal of Organisational Behaviour, 21, 525546. doi:10.1002/1099-1379(200008)21:5<525::AID-JOB40>3.0.CO;2-T

Robbins, S.P. (2005). Essentials of Organisational Behavior. New Jersey: Pearson.

Robbins, S.P., Odendaal, A., \& Roodt, G. (2004). Organisational Behaviour (Global and Southern African Perspectives). Cape Town: Pearson Education.

Saughnessy, J.J., \& Zechmeister, E.B. (1997). Research methods in Psychology. Singapore: McGraw-Hill. 
Samuel, M.O., Osinowo, H.O., \& Chipunza, C. (2009). The relationship between bank distress, job satisfaction, perceived stress and psychological well-being of
employees and depositors in Nigeria's banking sector. African Journal of Business Management, 3(11), 624-632.

Schultz, H., Bagraim, J., Potgieter, T., Viedge, C., \& Werner, A. (2003). Organisational Behaviour. A Contemporary South African Perspective. Pretoria: Van Schaik Publishers.

Shah, P.P. (2000). Network Distribution: The structural implications of downsizing. The Academy of Management Journal, 43(1), 101-112. doi:10.2307/1556389

Smith, C.A., Organ, D.W., \& Near, J.P. (1983). Organisational citizenship behaviour: Its nature and antecedents. Journal of Applied Psychology, 68, 653-663. doi:10.1037/0021-9010.68.4.653

Steiner, D.D., \& Bertolino, M. (2006). The Contribution of Organisational Justice Theory to Combating Discriminating. Retrieved February 02, 2009, from _http:// urmis.revues.org/index223.html
Tayyab, S. (2005). Organisational citizenship behaviour: Validating factor structure and invariance amongst employees. Journal of the Indian Academy of Applied Psychology, 31(1-2), 49-64.

The Universal Declaration of Human Rights. (1948). Retrieved May 04, 2011, from www.un.org/en/documents/udhr/index.Shtml

Thornhill, A., Lewis, P., Millmore, M., \& Saunders, M. (2000). Managing Change (A Human Resource Strategy Approach). Harlow: Prentice Hall.

Tourish, D., \& Hargie, O. (2004). The Communication Consequences of Downsizing Trust Loyalty and Commitment. Key Issues in Organisational Communication. Retrieved March 03, 2009, from http://www.questia.com/PM.qst?a=o\&d=104258524

Werner, A. (2007). Organisational behaviour, a contemporary South African perspective, $2^{\text {nd }}$ Edn. Pretoria: van Schaik.

Williams, G.C. (2004). Maintaining Organisational Commitment During Downsizing. MER Program. Newfoundland: Memorial University. 